\title{
Lead thrombus under standard-dose edoxaban in a patient with normal to high creatinine clearance and protein $\mathrm{S}$ deficiency
}

Wei-Chieh Lee ${ }^{1,2^{*}}$ (i) and Min-Ping Huang ${ }^{2}$

\begin{abstract}
Background: Non-vitamin K antagonist oral anticoagulants (NOACs) are as effective and safe as warfarin for thromboembolic prevention and treatment. The efficacy of NOACs lacks evidence from large and randomized studies in patients with inherited severe thrombophilia, including protein S deficiency. Further, some concerns still exist regarding the relative efficacy of edoxaban in preventing arterial thromboembolism in patients with normal to high creatinine clearance $(\mathrm{CrCl})$. We present a case of a rare complication of lead thrombus under standard-dose edoxaban in a patient with protein $\mathrm{S}$ deficiency and supernormal renal function.

Case presentation: A 65-year-old man experienced persistent chest tightness and a high level of D-dimer. Chest computed tomography (CT) showed a lead thrombus at the superior vena cava. He had a medical history including, paroxysmal atrial fibrillation (PAf), sick sinus syndrome after permanent pacemaker implantation, and transient ischemic attack. He received standard-dose edoxaban (60 mg daily) after PAf was diagnosed. His estimated $\mathrm{CrCl}$ was $98.6-102.1 \mathrm{~mL} / \mathrm{min}$. However, protein S deficiency (22.8\%; normal range: 55-130\%) was diagnosed. After switching to dabigatran (150 mg twice daily) for 3 months, the chest CT showed lead thrombus resolution and no symptoms were seen during the follow-up period.

Conclusions: This case was a rare complication of lead thrombus in a protein $\mathrm{S}$ deficient patient with normal renal function receiving standard-dose edoxaban. Edoxaban efficacy is uncertain in patients with protein $\mathbf{S}$ deficiency, and intracardiac devices also increase the risk of thromboembolic events.
\end{abstract}

Keywords: Lead thrombus, Edoxaban, Paroxysmal atrial fibrillation, Protein S deficiency

\section{Background}

Non-vitamin K antagonist oral anticoagulants (NOACs) are as effective and safe as warfarin for thromboembolic prevention. In patients with inherited severe thrombophilia, including protein $\mathrm{S}$ deficiency, the efficacy of

\footnotetext{
* Correspondence: leeweichieh@yahoo.com.tw

'Institute of Clinical Medicine, College of Medicine, National Cheng Kung University, Tainan, Taiwan

${ }^{2}$ Department of Internal Medicine, Division of Cardiology, Kaohsiung Chang Gung Memorial Hospital, Chang Gung University College of Medicine, 123,

Ta Pei Road, Niao Sung District, Kaohsiung City 83301, Taiwan
}

NOACs is still controversial. Some concerns still exist regarding the relative efficacy of edoxaban in preventing arterial thromboembolism in patients with normal to high creatinine clearance $(\mathrm{CrCl})$. We present the case of a thromboembolic event (lead thrombus) that occurred from using standard-dose edoxaban in a patient with paroxysmal atrial fibrillation (PAf) and protein $\mathrm{S}$ deficiency but with normal renal function.

(c) The Author(s). 2021 Open Access This article is licensed under a Creative Commons Attribution 4.0 International License, which permits use, sharing, adaptation, distribution and reproduction in any medium or format, as long as you give appropriate credit to the original author(s) and the source, provide a link to the Creative Commons licence, and indicate if changes were made. The images or other third party material in this article are included in the article's Creative Commons licence, unless indicated otherwise in a credit line to the material. If material is not included in the article's Creative Commons licence and your intended use is not permitted by statutory regulation or exceeds the permitted use, you will need to obtain permission directly from the copyright holder. To view a copy of this licence, visit http://creativecommons.org/licenses/by/4.0/. The Creative Commons Public Domain Dedication waiver (http://creativecommons.org/publicdomain/zero/1.0/) applies to the data made available in this article, unless otherwise stated in a credit line to the data. 


\section{Case presentation}

A 56-year-old man experienced chest tightness for hours, which gradually worsened for a day. Chest discomfort was more severe at the peak of inhalation. The tenderness was located at the central and upper chest wall, which radiated to the back. No cold sweating or compression was observed. He visited our emergency department for advanced evaluation and treatment. Electrocardiography showed normal pacemaker rhythm and no ST-T segment changes. Cardiac biomarker levels were normal, but a high D-dimer level $(6.57 \mathrm{mg} / \mathrm{L}$; normal range: $<0.5 \mathrm{mg} / \mathrm{L}$ ) was noted. Emergency chest computed tomography (CT) revealed no pulmonary embolism but presented a filling defect in the right internal jugular vein and superior vena cava, which was highly suspected lead thrombosis (Fig. 1A, B; white arrows). Due to persistent symptoms, we did not suspect flow artefact or laminal effects.

The patient had a medical history of transient ischemic attack 7 years earlier. He also experienced dizziness and was diagnosed with PAf and sick sinus syndrome with long pauses ( $>3 \mathrm{~s}$ ) 2 years ago. After being diagnosed with PAf, he received standard-dose edoxaban $(60 \mathrm{mg})$ daily for stroke prevention and received a transvenous permanent pacemaker for symptomatic bradycardia. $\mathrm{CrCl}$ estimated by the Cockcroft-Gault formula was supernormal to normal $(98.6-102.1 \mathrm{~mL} / \mathrm{min})$. The burden of PAf was approximately $0.2-1 \%$ in pacemaker records after pacemaker implantation and the use of antiarrhythmic agents (amiodarone $100 \mathrm{mg}$ daily). Intracardiac electrogram did not detect any atrial high rate in the last 3 months but noted protein S deficiency (22.8\%; normal range: $55-130 \%)$. He did not receive pglycoprotein or CYP3A4 inducers but did receive lowdose atorvastatin (10 mg daily). Then, $150 \mathrm{mg}$ dabigatran twice daily was administered to resolve the thrombus and secondary prevention of thromboembolic events. Three months later, chest CT also showed no filling defect and no residual lead thrombus (Fig. 1C, D; black arrows). The patient denied recurrent chest discomfort during the half-year follow-up period. His medical history is listed in Fig. 2 and his biological characteristics are listed in Table 1.

\section{Discussion}

This was a case of lead thrombus under standard-dose edoxaban and a diagnosis of protein $\mathrm{S}$ deficiency. The patient still had a medical history of PAf, but a low burden $(0.2-1 \%)$ was noted in the intracardiac electrogram. No strong drug-drug interaction was noted, and the patient also presented good medical adherence. Low-dose atorvastatin did not affect the efficacy of edoxaban. Because he had supernormal to normal renal function, inadequate protection against thromboembolic events caused by edoxaban needed to be considered. Protein $S$ deficiency and intracardiac devices also increased the risk of thromboembolism. Edoxaban was switched to dabigatran (150 mg twice daily), and chest CT 3 months later revealed resolution of the lead thrombus. The associated chest discomfort was also resolved. Therefore, there are three potential underlying reasons for the therapeutic failure in the present case: first, a high-risk patient with protein S deficiency; second, uncertain edoxaban efficacy in the presence of an intracardiac device; and third, uncertain edoxaban efficacy in a patient with normal renal function.

In large randomized controlled trials, NOACs have been shown to be as effective and safe as warfarin [1-4]. NOACs also reduced the composite end point of stroke (odds ratio $=0.65$ ) and systemic embolic events (odds ratio $=0.85)$ when compared with warfarin [5]. Edoxaban acts as a direct factor $\mathrm{Xa}$ inhibitor and renal clearance accounts for approximately $50 \%$ of the total clearance of edoxaban [6]. There are some concerns regarding the relative efficacy of edoxaban in preventing arterial thromboembolism in patients with $\mathrm{CrCl}>95 \mathrm{~mL} / \mathrm{min}$ [7]. Such concerns are of particular interest considering the United States Food and Drug Administration label, which restricts its use in patients with $\mathrm{CrCl}>95 \mathrm{~mL} / \mathrm{min}$ because of concerns of decreased efficacy in preventing arterial thromboembolism compared with warfarin [8]. However, both doses of edoxaban have been associated with reduced risks of stroke and systemic embolism without decreased efficacy when standard-dose edoxaban has been used in the presence of higher $\mathrm{CrCl}(>95$ $\mathrm{mL} / \mathrm{min}$ ) in real-world practice [9].

Pacemaker implantation is complicated by major thromboembolic events in $0.6-3.5 \%$ of cases [10]. One case report stated pacemaker-associated thrombosis in ongoing therapy with reduced-dose edoxaban [11]. Few previous reports have discussed thromboembolic events in patients with supernormal or normal renal function. Two other case reports have presented lead thrombi under other anti-factor Xa inhibitors [12, 13]. NOACs have comparable efficacy to warfarin for treating and preventing venous thromboembolisms (VTEs) [14]. Natural anticoagulant deficiencies (protein $\mathrm{C}$, protein $\mathrm{S}$, or anti-thrombin), homozygous factor $\mathrm{V}$ Leiden (FVL), and prothrombin G20210A, or combined defects, result in a severe thrombophilic phenotype, occurring in approximately $5 \%$ of patients with idiopathic VTE [15]. However, few studies have focused on the efficacy of NOACs for the treatment of inherited severe thrombophilia. A case series reported lower efficacy of NOACs in patients with protein S deficiency [16], but it did not present any data regarding edoxaban. In two meta-analyses, the rates of VTE recurrence were both low and were comparable in patients with various thrombophilias receiving either 


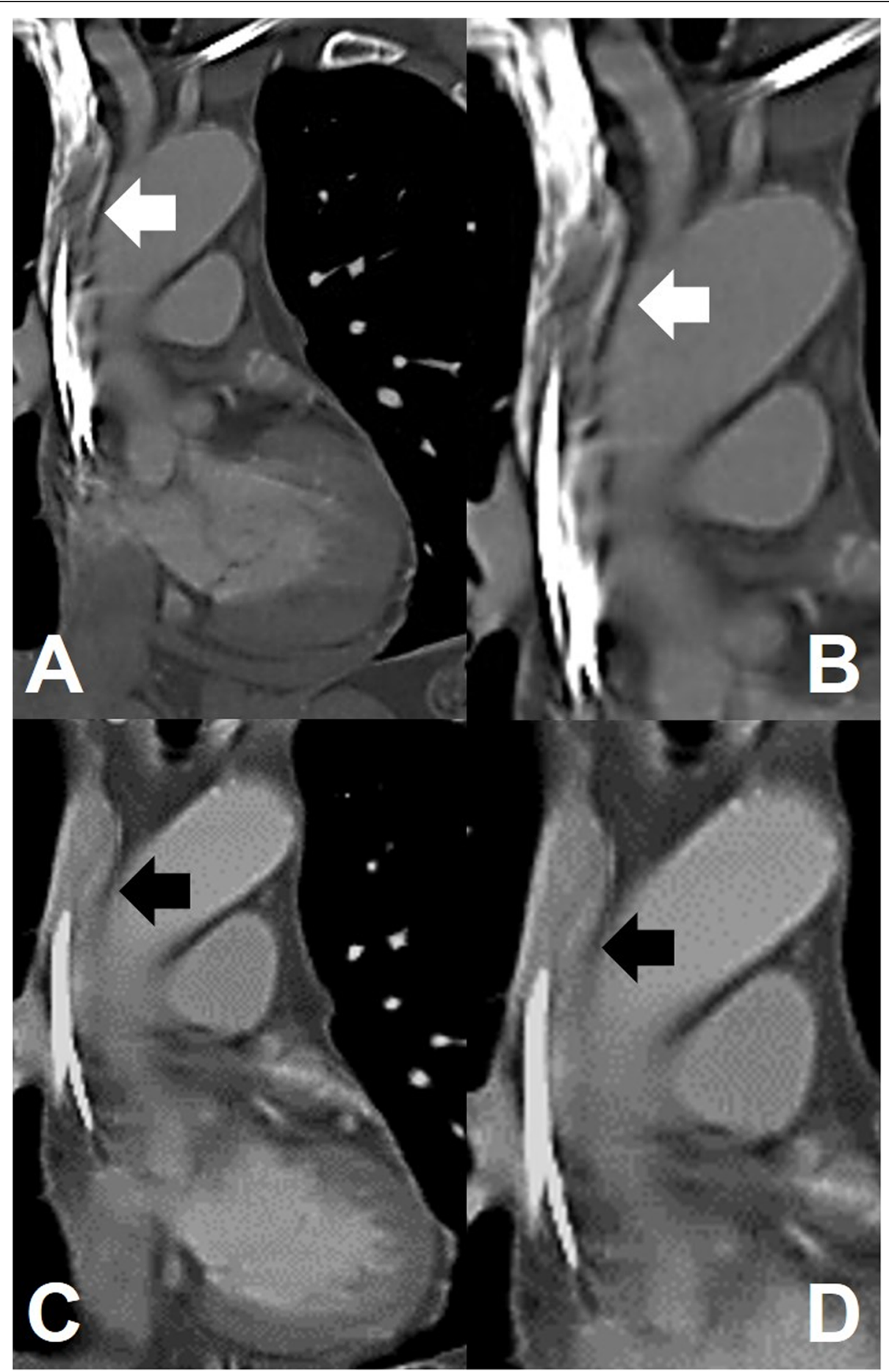

Fig. 1 Chest computed tomography. A, B. A filling defect in the right internal jugular vein and superior vena cava was noted with highly suspected lead thrombosis coated on the pacemaker leads (white arrows). Follow-up chest computed tomography. C, D. No filling defect and no residual lead thrombus were noted (black arrows)

treatment; therefore, NOACs are an appropriate treatment option in this population $[14,17]$.

In clinical practice, NOAC therapy does not require routine monitoring of NOAC levels for dose adjustment $[18,19]$. However, NOAC level measurement needs to be considered if the patients present special situations including, (A) acute or chronic renal insufficiency; (B) thrombolytic therapy consideration; $(C)$ clinically significant bleeding; (D) therapeutic failure with recurrent VTE; or (E) urgent or emergent invasive procedures [20, 


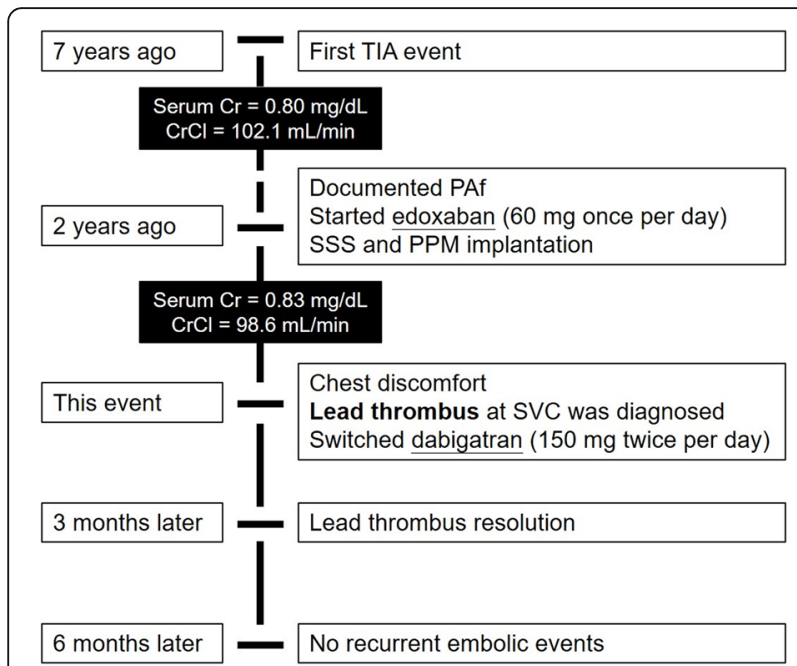

Fig. 2 Perspective section about medical history. Abbreviations: TIA: transient ischemic attack; $\mathrm{Cr}$ : creatinine; $\mathrm{CrCl}$ : creatinine clearance; PAf: paroxysmal atrial fibrillation; SSS: sick sinus syndrome; PPM: permanent pacemaker; SVC: superior vena cava

21]. Additionally, there are other scenarios where NOAC levels could be useful such as in patients with extreme body weights, the presence of interacting medications, and confirmation of chronic anticoagulation following the initial loading period [22]. Unfortunately, NOAC level measurements were not available in our hospital, so we did not know the efficacy of edoxaban in this patient with protein $\mathrm{S}$ deficiency, an intracardiac device, and normal renal function. Therefore, we switched to the direct thrombin inhibitor dabigatran to solve the therapeutic failure of edoxaban. Fortunately, the lead thrombus resolved, and no recurrent thromboembolic events happened in the follow-up period.

Table 1 Summary of biological characteristics

\begin{tabular}{lll}
\hline Variable & Value & Normal range \\
\hline D-dimer (mg/L) & 6.57 & $<0.5$ \\
Creatinine (mg/dL) & $0.80-0.83$ & $0.64-1.27$ \\
Estimated CrCl (mL/min) & $102.12-98.57$ & \\
Anti-thrombin III (\%) & 99.2 & $75-125$ \\
Protein-S (\%) & 22.8 & $55-130$ \\
Protein-C (\%) & 77.3 & $70-140$ \\
C3 (mg/dL) & 116.00 & $90-180$ \\
C4 (mg/dL) & 21.30 & $10-40$ \\
ANA & negative & negative \\
A-DSDNA (WHOunit/mL) & $<40.5$ & $<92.6$ \\
\hline
\end{tabular}

Abbreviation: $\mathrm{CrCl}$ Creatinine clearance, ANA Antinuclear antibody, A-DSDNA Anti-double stranded DNA

\section{Conclusions}

This case was a rare complication of lead thrombus in a patient with normal renal function receiving standarddose edoxaban. Eoxaban inefficacy can be suspected in patients with protein $\mathrm{S}$ deficiency, and intracardiac devices also increase the risk of thromboembolic events.

\section{Acknowledgements}

None.

Disclosures

None.

\section{Authors' contributions}

WC Lee wrote the manuscript. MP Huang prepared the figures and table. WC Lee did the final revision. All authors reviewed and approved the final manuscript.

Funding

None.

Availability of data and materials

Data available on request from the authors.

\section{Declarations}

Ethics approval and consent to participate

This case report followed the ethical standards of the responsible committee on human experimentation and with the Helsinki Declaration of 1964 and later revisions.

\section{Consent for publication}

All authors read and approved this manuscript for publication.

\section{Competing interests}

None.

Received: 8 March 2021 Accepted: 7 July 2021

Published online: 17 July 2021

\section{References}

1. Connolly SJ, Ezekowitz MD, Yusuf S, Eikelboom J, Oldgren J, Parekh A, et al. Dabigatran versus warfarin in patients with atrial fibrillation. N Engl I Med. 2009;361 (12):1139-51. https://doi.org/10.1056/NEJMoa0905561.

2. Patel MR, Mahaffey KW, Garg J, Pan G, Singer DE, Hacke W, et al. Rivaroxaban versus warfarin in nonvalvular atrial fibrillation. N Engl J Med. 2011;365(10):883-91. https://doi.org/10.1056/NEJMoa1009638.

3. Granger CB, Alexander JH, McMurray JJ, Lopes RD, Hylek EM, Hanna M, et al. Apixaban versus warfarin in patients with atrial fibrillation. N Engl J Med. 2011;365(11):981-92. https://doi.org/10.1056/NEJMoa1107039.

4. Giugliano RP, Ruff $C T$, Braunwald E, Murphy SA, Wiviott SD, Halperin $J$, et al. Edoxaban versus warfarin in patients with atrial fibrillation. N Engl J Med. 2013;369(22):2093-104. https://doi.org/10.1056/NEJMoa1310907.

5. Wang KL, Lip GY, Lin SJ, Chiang CE. Non-vitamin K antagonist Oral anticoagulants for stroke prevention in Asian patients with Nonvalvular atrial fibrillation: meta-analysis. Stroke. 2015;46(9):2555-61. https://doi.org/1 0.1161/STROKEAHA.115.009947

6. Ogata K, Mendell-Harary J, Tachibana M, Masumoto H, Oguma T, Kojima M, et al. Clinical safety, tolerability, pharmacokinetics, and pharmacodynamics of the novel factor Xa inhibitor edoxaban in healthy volunteers. J Clin Pharmacol. 2010;50(7):743-53. https://doi.org/10.1177/0091270009351883.

7. Bohula EA, Giugliano RP, Ruff CT, Kuder JF, Murphy SA, Antman EM, et al. Impact of renal function on outcomes with edoxaban in the ENGAGE AFTIMI 48 trial. Circulation. 2016;134(1):24-36. https://doi.org/10.1161/CIRCULA TIONAHA. 116.022361.

8. US Food and Drug Administration. Prescribing information for Savaysa (edoxaban). 2015. http://www.accessdata.fda.gov/drugsatfda_docs/label/201 5/206316lbl.pdf. Accessed 22 Feb 2018.

9. Yu HT, Yang PS, Kim TH, Jang E, Kim D, Uhm JS, et al. Impact of renal function on outcomes with edoxaban in real-world patients with atrial 
fibrillation. Stroke. 2018;49(10):2421-9. https://doi.org/10.1161/STROKEA HA.118.021387.

10. Barakat K, Robinson NM, Spurrell RA. Transvenous pacing lead-induced thrombosis: a series of cases with a review of the literature. Cardiology. 2000;93(3):142-8. https://doi.org/10.1159/000007018.

11. Di Vincenzo A, Rizzo A, Russo L, Mioni R. Pacemaker-associated thrombosis in ongoing therapy with edoxaban tosylate. J Thromb Thrombolysis. 2018; 46(4):549-50. https://doi.org/10.1007/s11239-018-1733-z.

12. Michałek P, Kubaszek-Kornatowska A, Pręgowska-Chwała B. Późna zakrzepica żyły podobojczykowej lewej po wszczepieniu układu stymulującego skutecznie leczona riwaroksabanem [Late pacemaker lead thrombosis treated with rivaroxaban]. Kardiol Pol. 2014;72(9):840. https://doi.org/10. 5603/KP.2014.0173.

13. Adar A, Önalan O, Cakan F. Development of pacemaker Lead thrombosis in a patient with atrial fibrillation during Apixaban treatment. J Tehran Heart Cent. 2019;14(4):183-6.

14. van der Hulle T, Kooiman J, den Exter PL, Dekkers OM, Klok FA, Huisman MV. Effectiveness and safety of novel oral anticoagulants as compared with vitamin $\mathrm{K}$ antagonists in the treatment of acute symptomatic venous thromboembolism: a systematic review and meta-analysis. J Thromb Haemost. 2014;12(3):320-8. https://doi.org/10.1111/jth.12485.

15. Franchini M, Veneri D, Salvagno GL, Manzato F, Lippi G. Inherited thrombophilia. Crit Rev Clin Lab Sci. 2006;43(3):249-90. https://doi.org/10.1 080/10408360600552678.

16. Undas A, Goralczyk T. Non-vitamin K antagonist oral anticoagulants in patients with severe inherited thrombophilia: a series of 33 patients. Blood Coagul Fibrinolysis. 2017;28(6):438-42. https://doi.org/10.1097/MBC. 0000000000000613.

17. Elsebaie MAT, van Es N, Langston A, Büller HR, Gaddh M. Direct oral anticoagulants in patients with venous thromboembolism and thrombophilia: a systematic review and meta-analysis. J Thromb Haemost. 2019;17(4):645-56. https://doi.org/10.1111/jth.14398.

18. Eikelboom JW, Quinlan DJ, Hirsh J, Connolly SJ, Weitz Jl. Laboratory monitoring of non-vitamin $\mathrm{K}$ antagonist Oral anticoagulant use in patients with atrial fibrillation: a review. JAMA Cardiol. 2017;2(5):566-74. https://doi. org/10.1001/jamacardio.2017.0364.

19. Rottenstreich A, Zacks N, Kleinstern G, Raccah BH, Roth B, Da'as N, et al. Direct-acting oral anticoagulant drug level monitoring in clinical patient management. J Thromb Thrombolysis. 2018;45(4):543-9. https://doi.org/10.1 007/s11239-018-1643-0.

20. Weitz Jl, Eikelboom JW. Urgent need to measure effects of direct Oral anticoagulants. Circulation. 2016;134(3):186-8. https://doi.org/10.1161/ CIRCULATIONAHA.116.022307.

21. Tripodi A, Ageno W, Ciaccio M, Legnani C, Lippi G, Manotti C, et al. Position paper on laboratory testing for patients on direct oral anticoagulants. A consensus document from the SISET, FCSA, SIBioC and SIPMeL. Blood Transfus. 2018;16(5):462-70. https://doi.org/10.2450/2017.0124-17.

22. Tripodi A. The laboratory and the new oral anticoagulants. Clin Chem. 2013, 59(2):353-62. https://doi.org/10.1373/dlinchem.2012.189704

\section{Publisher's Note}

Springer Nature remains neutral with regard to jurisdictional claims in published maps and institutional affiliations.

Ready to submit your research? Choose BMC and benefit from:

- fast, convenient online submission

- thorough peer review by experienced researchers in your field

- rapid publication on acceptance

- support for research data, including large and complex data types

- gold Open Access which fosters wider collaboration and increased citations

- maximum visibility for your research: over $100 \mathrm{M}$ website views per year

At $\mathrm{BMC}$, research is always in progress.

Learn more biomedcentral.com/submissions 